\title{
Importance of food allergy and food intolerance in allergic multimorbidity
}

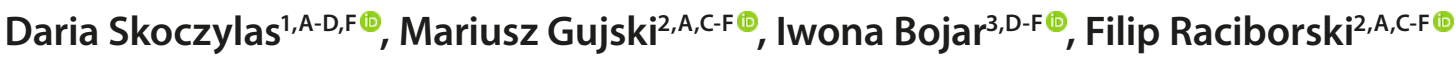 \\ ${ }^{1}$ Faculty of Health Sciences, Medical University, Warsaw, Poland \\ ${ }^{2}$ Department of Prevention of Environmental Hazards and Allergology, Medical University, Warsaw, Poland \\ ${ }^{3}$ Department of Women's Health, Institute of Rural Health, Lublin, Poland \\ $A$ - Research concept and design, B - Collection and/or assembly of data, C - Data analysis and interpretation, \\ $D$ - Writing the article, E - Critical revision of the article, F - Final approval of article
}

Skoczylas D, Gujski M, Bojar I, Raciborski F. Importance of food allergy and food intolerance in allergic multimorbidity. Ann Agric Environ Med. 2020; 27(3): 413-417. doi: 10.26444/aaem/123107

\begin{abstract}
Introduction. Allergy affects approximately one-third of the world's population, and the rates are growing. In Europe, it has been noticed that the risk of asthma and allergy is lower in the rural as opposed to urban population. There is a tendency for several allergic diseases to be present in the same person at the same time.

Objective. The aim of the study was to verify the co-occurrence of allergic multimorbidity and food allergy and intolerance in a group of children.

Materials and method. The multicentre cross-sectional study enrolled 1,008 children and adolescence aged 6-18 years (51.2\% boys, $48.8 \%$ girls). The study comprised a questionnaire (respondents' declarations) and an outpatient examination (diagnostic examination followed by a medical diagnosis). The study was conducted as part of the 2016-2020 National Health Programme.

Results. In the study group, allergic rhinitis (AR) was present in $46.4 \%$, bronchial asthma (BA) in $11.2 \%$ and atopic dermatitis (AD) in $6 \%$. Allergic multimorbidity (simultaneous presence of 2 or more of the allergic diseases AR, BA and AD) was diagnosed in $9.7 \%$. A single allergic disease (of the 3 ) was diagnosed in $43.4 \%$. A diagnosis of food allergy and food intolerance was reported respectively at $29.6 \%$ and $14.3 \%$ participants with doctor-diagnosed allergic multimorbidity. Among those without any of the 3 allergic diseases, the percentage were $14.4 \%$ and $9.1 \%$, respectively.

Conclusions. Food allergy or food intolerance was more common in subjects with allergic multimorbidity than in subjects diagnosed with one allergic disease or those free of allergic diseases.
\end{abstract}

\section{Key words}

multimorbidity, Polysensitization, food allergy, asthma, Rhinitis, atopic dermatitis

\section{Abbreviations}

ISAAC - International Study of Asthma and Allergy In Childhood; ECRHS II - European Community Respiratory Health Survey II; BA - bronchial asthma; AR - allergic rhinitis; AD - atopic dermatitis; FI - food intolerance; WHO - World Health Organisation; FA - food allergy; ECAP - Epidemiology of Allergic Diseases in Poland; ARIA - Allergic Rhinitis and its Impact on Asthma

\section{INTRODUCTION}

Allergy is a hypersensitivity reaction involving immune mechanisms mediated by inflammatory cells or antibodies $[1,2]$. Allergy affects approximately one-third of the world's population $[3,4,5]$, and the rates are growing [6]. Allergies are a significant public health problem in both developed and developing countries [3-5, 7]. Differences in the prevalence of allergic diseases between urban and rural areas exist in many parts of the world. Research in Africa and Asia has shown that the burden of allergic disease is lower in rural populations [8]. In Europe, too, it has been noticed that the risk of asthma and allergy is lower in the rural as opposed to urban population [9]. The results of 2 epidemiological studies (International Study of Asthma and Allergy In Childhood [ISAAC] and European Community Respiratory Health Survey II [ECRHS II]) reveal a growing prevalence of bronchial asthma (AR), rhinitis (AR), atopic dermatitis (AD) and food allergy (FA) [6]. These trends

Address for correspondence: Iwona Bojar, Department of Women's Health, Institute of Rural Health, Lublin, Poland

E-mail: iwonabojar75@gmail.com

Received: 11.05.2020; accepted: 29.05.2020; first published: 09.06.2020 are particularly visible among children [3]. As stated in the Allergy White Book, the highest increases in prevalence over the last century have been observed for AR $(1 \%-20 \%$ of the population), BA (2-fold increase in the number of patients) and AD (now affecting 24\% of children under 7 years of age) $[3,5]$. According to the relevant literature, food allergy affects $2-3 \%$ of the world's population [3]. At the same time, social awareness about causative factors for food allergy has been growing [10]. The most common animal-derived food allergens that also most often cause food allergy in infants are cow's milk proteins, which are responsible for $2.0-3.5 \%$ of all food allergies, and eggs, causing $1.3-3.2 \%$ of allergies, while nuts, wheat flour, soybean and fish more often cause allergies in adults $[10,11,12]$. Clinical manifestations following ingestion of sensitising food may be shared by allergy, which is caused by immune-mediated mechanisms, and food intolerance (FI) [13], associated with non-immune-mediated mechanisms [14].

According to the WHO, allergic asthma - an immunemediated disease - ranks among the most common chronic medical conditions, affecting approximately $4 \%$ of the global population and $10 \%$ of Europeans [15, 16]. The Global Initiative for Asthma report estimated the prevalence of 
asthma in various countries at $1 \%-18 \%$ of the population [16]. The ISAAC study found that asthma is more common in developed countries, while in developing countries it is more severe in children. The ECAP (Epidemiology of Allergic Diseases in Poland) study found that asthma affects $2-7 \%$ of children in the Polish population between 6 and 7 years of age and $4-10 \%$ of those aged 13-14 years [5].

Another allergic disease is atopic dermatitis (AD), which affects about $3 \%$ of adults and about $20 \%$ of children worldwide [17], and manifests as a chronic and recurrent dermatitis with eczematous foci, pruritus, exfoliation and dry skin $[17,18$, 19]. The highest incidence of $\mathrm{AD}$ is in the first year of life, and onset before the age of 5 years occurs in $90 \%$ of cases [19]. The aetiopathogenesis of AD is not fully elucidated, but a genetic background has been established [20,21].

The most common allergic disease is allergic rhinitis (AR), with both environmental and genetic factors playing a role in its aetiology. It affects $10-20 \%$ of the world population, with Poland ranking among the European countries with the highest rates of AR [22]. AR is an inflammatory reaction of the nasal mucosa to an allergen, manifesting as a watery discharge, sneezing and nasal congestion and itching [23]. Research shows that early signs appear before the age of 20 in $80 \%$ of patients [22]. There is a tendency for several allergic diseases to be present in the same person at the same time. This is particularly noticeable in childhood [24].

According to the ARIA (Allergic Rhinitis and its Impact on Asthma) classification, there is a close relationship between bronchial asthma and allergic rhinitis. Research shows that about $80 \%$ of BA patients also suffer from AR [22]. Respiratory allergic disease also co-occurs with atopic dermatitis syndrome. Co-existing manifestations of $\mathrm{AD}$ and asthma are seen in $20 \%$ of children [25]. Allergic rhinitis, asthma, AD and food allergies are allergic diseases sharing IgE antibody-mediated causative mechanisms [26]. Children with $\mathrm{AD}$, asthma or $\mathrm{AR}$ are at a higher risk for food allergies than healthy children $[27,28]$. Research to date has mostly focused on the description of relationships between asthma, $\mathrm{AD}$ and $\mathrm{AR}$ [29], while data on the link between these diseases and food allergy are scarce [30].

\section{OBJECTIVE}

The aim of the study is to demonstrate in a group of children the concomitant presence of allergic multimorbidity on the one hand, and food allergy and intolerance on the other.

\section{MATERIALS AND METHOD}

The study enrolled 1,008 participants classified into the following 3 age groups: 6-9 years, 10-14 years and 15-18 years, with 516 boys (51.2\%) and 492 girls (48.8\%). Inclusion criteria comprised age between 6 - 18 years, and informed consent obtained from a parent or guardian of the child to participate in the study. The exclusion criteria comprised the use of anti-allergic medication during the 7 days preceding the study, upper or lower respiratory infection, poor general health, severe systemic disease, and poor compliance on the part of the legal guardian and/or the child.

The study had a multicentre design and was carried out in selected health care facilities in 3 major Polish cities:
Warsaw (505 children), Łódź (252 children) and Poznań (251 children). Participation was voluntary and sampling was based on the availability of subjects (convenience sample).

The following definitions of multimorbidity and polysensitisation were adopted for the purposes of the study: allergic multimorbidity - concomitant presence of at least 2 of the following 3 allergic diseases: bronchial asthma (BA), allergic rhinitis (AR) and atopic dermatitis (AD). Polysensitisation - sensitisation to at least 2 allergens or groups of allergens (sensitisation to 2 allergens of the same group is not considered polysensitisation) [29].

The study was conducted within the 2016 - 2020 National Health Programme framework in the last quarter of 2017. It was a cross-sectional study comprised of a questionnaire (respondents' declarations) and an outpatient examination (diagnostic examination followed by a medical diagnosis). For the questionnaire part, the children's parent or legal guardian answered 38 questions about manifestations of allergic diseases (in particular BA, AR and AD). The questions concerned a previous diagnosis of food allergy or intolerance previously made by a medical professional, and the occurrence of symptoms of food allergy and intolerance (and their severity) following consumption of selected food products, such as milk and milk products, eggs, peanuts, hazelnuts and other nuts, fish, seafood, celery, fruit (including citrus), soybean, poultry, pork, beef, wheat/gluten and food additives. The signs and symptoms produced by food consumption were divided into the following 2 groups:

- allergic symptoms (itching rash on a part of the body, itching rash all over the body, shortness of breath and fainting);

- other symptoms (diarrhoea, feeling generally ill).

For the second part of the study, the participants were examined by a consulting allergist, which included a spirometry test with bronchodilator challenge (Salbutamolum 400ug) and skin prick testing for 15 allergens: birch (108), grass/cereals (15), mugwort (106), D.pteronyssinus (725), hen's egg (604), cow's milk (601), dog (306), cat (309), D. farinae (708), hazel (129), alder (115), rye (158), plantain (Plantago) (169), Cladosporium herbarum (406), Alternaria tenuis (400), histamine (902) and a control (901). Diagnoses declared by the subjects were used for the analysis.

Statistical analysis was carried out using IBM SPSS ver. 24. Statistical significance was tested with Pearson's chi-squared tests. The threshold for significance was assumed at $\mathrm{p}<0.05$.

The Ethical Review Board at the Medical University of Warsaw determined that the study was admissible and compliant with the principles of scientific ethics (Decision No. KB/160/2017).

\section{RESULTS}

In the study group, AR was present in $46.4 \%$ (52.1\% of boys vs $40.4 \%$ of girls; $\mathrm{p}<0.001)$, BA in $11.2 \%$ ( $13.0 \%$ of boys and $9.3 \%$ of girls: $\mathrm{p}=0.073)$ and $\mathrm{AD}$ in $6 \%(4.3 \%$ of boys and $7.7 \%$ of girls; $\mathrm{p}<0.05)$.

Allergic multimorbidity (simultaneous presence of 2 or more of the allergic diseases AR, BA and AD) was diagnosed in $9.7 \%$ of the study group (11.2\% of boys and $8.1 \%$ of girls; $\mathrm{p}<0.01$ ). A single allergic disease (of the 3 ) was diagnosed in $43.4 \%$ of the group ( $46.5 \%$ of boys and $40.0 \%$ of girls; $p<0.01$ ). 
Table 1. General characteristics of study group

\begin{tabular}{|c|c|c|}
\hline Parameter & Value & $\begin{array}{l}\text { percentage } \\
{[\%]}\end{array}$ \\
\hline \multirow{3}{*}{ Age } & $6-9$ years & 36.9 \\
\hline & $10-14$ years & 43.3 \\
\hline & $15-18$ years & 19.8 \\
\hline \multirow{2}{*}{ Gender } & Girl & 48.8 \\
\hline & Boy & 51.2 \\
\hline \multirow{3}{*}{ Site (city) } & Łódź & 25.0 \\
\hline & Poznań & 24.9 \\
\hline & Warsaw & 50.1 \\
\hline \multirow{2}{*}{ AR diagnosed by doctor } & No & 53.6 \\
\hline & Yes & 46.4 \\
\hline \multirow{2}{*}{ AR diagnosed by doctor, breakdown by gender } & Girl & 40.4 \\
\hline & Boy & 52.1 \\
\hline \multirow{2}{*}{ BA diagnosed by doctor } & No & 88.8 \\
\hline & Yes & 11.2 \\
\hline \multirow{2}{*}{ BA diagnosed by doctor, breakdown by gender } & Girl & 9.3 \\
\hline & Boy & 13.0 \\
\hline \multirow{2}{*}{ AD diagnosed by doctor } & No & 94.0 \\
\hline & Yes & 6.0 \\
\hline \multirow{2}{*}{ AD diagnosed by doctor, breakdown by gender } & Girl & 7.7 \\
\hline & Boy & 4.3 \\
\hline \multirow{2}{*}{ Multimorbidity } & No & 90.3 \\
\hline & Yes & 9.7 \\
\hline \multirow{2}{*}{ Multimorbidity, breakdown by gender } & Girl & 8.1 \\
\hline & Boy & 11.2 \\
\hline \multirow{2}{*}{$\begin{array}{l}\text { Food allergy diagnosed by doctor (as reported by } \\
\text { participant) }\end{array}$} & No & 81.9 \\
\hline & Yes & 18.1 \\
\hline \multirow{2}{*}{$\begin{array}{l}\text { Food intolerance diagnosed by doctor (as reported } \\
\text { by participant) }\end{array}$} & No & 91.2 \\
\hline & Yes & 8.8 \\
\hline
\end{tabular}

Food allergy or food intolerance was reported by a total of $24.1 \%$ of the participants, with $18.1 \%$ declaring doctordiagnosed food allergy and $8.8 \%$ declaring food intolerance (Table 1). There were no statistically significant differences according to gender.

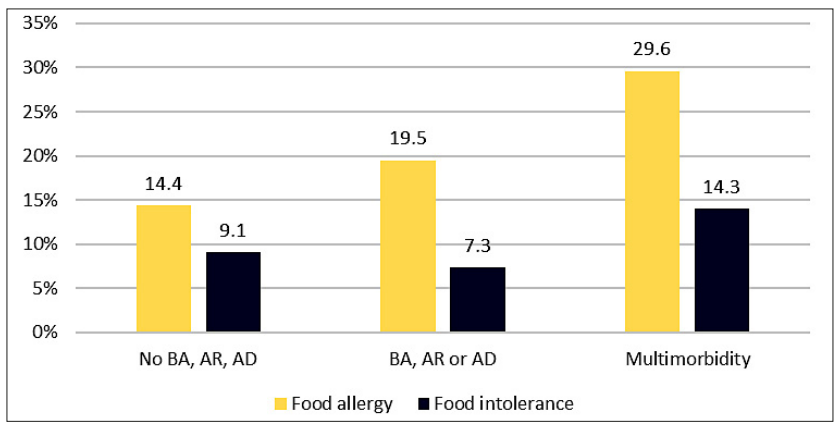

Figure 1. Prevalence of food allergy and food intolerance as reported by participants:

a) without symptoms of $A R, B A$ and $A D$ (leftmost),

b) with a single diagnosed allergic disease (centre),

c) with allergic multimorbidity (rightmost).

A diagnosis of food allergy and food intolerance was more often reported by participants with doctor-diagnosed allergic multimorbidity. Those subjects were nearly twice as likely to have food allergy as those not diagnosed with any of the three allergic diseases (Fig. 1).
Subjects with allergic multimorbidity declared symptoms of food allergy or food intolerance more often than subjects without $\mathrm{BA}, \mathrm{AR}$ or $\mathrm{AD}$, or those with a diagnosis of only one of these diseases with regard to 12 out of the 14 groups of food products analysed (Tab. 3). The opposite correlation was noted only for soybean and wheat. Among those with allergic multimorbidity, the highest percentages declared food allergy to or intolerance of milk and milk products (22.4\%), fruit, including citrus (16.3\%), hazelnuts and other nuts (12.2\%), peanuts (10.2\%) and eggs (9.2\%).

For comparison, among the subjects diagnosed with just one allergic disease (AR, BA or AD), the percentages were as follows: $14.6 \%$ (milk), $8.2 \%$ (citrus), $4.3 \%$ (hazelnuts), $3 \%$ (peanuts) and 3.2\% (eggs). All these differences were statistically significant (Tab. 3).

Table 2. Symptoms of food allergy and food intolerance following consumption of specific food products $(\mathrm{N}=1008)$

\begin{tabular}{lcc}
\hline Causative food product & $\begin{array}{c}\text { Symptoms of allergy* } \\
{[\%]}\end{array}$ & $\begin{array}{c}\text { Other symptoms** } \\
{[\%]}\end{array}$ \\
\hline Milk and milk products & 14.0 & 14.2 \\
\hline Eggs & 2.9 & 2.7 \\
\hline Peanuts & 3.3 & 2.3 \\
\hline Hazelnuts and other nuts & 4.5 & 2.3 \\
\hline Fish & 1.3 & 1.0 \\
\hline Seafood & 0.7 & 0.9 \\
\hline Celery & 1.2 & 0.7 \\
\hline Fruit, including citrus & 8.6 & 2.8 \\
\hline Soybeans & 1.0 & 1.0 \\
\hline Poultry & 0.4 & 0.8 \\
\hline Pork, beef & 0.7 & 0.9 \\
\hline Wheat/ gluten & 2.4 & 3.7 \\
\hline Food additives & 3.3 & 2.9 \\
\hline Other & 6.7 & 4.3 \\
\hline
\end{tabular}

*Symptoms of allergy (itching rash on a part of the body, itching rash all over the body, shortness of breath, fainting).

**Other symptoms (diarrhoea, feeling generally ill)

Table 3. Food products producing symptoms of food allergy and food intolerance by allergy status (no other diagnoses, diagnosed with one of the three allergic diseases $[A R, B A$ or $A D]$, allergic multimorbidity) $(\mathrm{N}=1008)$

\begin{tabular}{lcccc}
\hline $\begin{array}{l}\text { Food product producing } \\
\text { symptoms of food allergy } \\
\text { and food intolerance }\end{array}$ & $\begin{array}{c}\text { No allergic } \\
\text { diseases }\end{array}$ & $\begin{array}{c}\text { Single allergic } \\
\text { disease }\end{array}$ & $\begin{array}{c}\text { Multi- } \\
\text { morbidity }\end{array}$ & $\mathrm{p}$ \\
\hline Mild and milk products & 11.6 & 14.6 & 22.4 & $\mathrm{p}<0.05$ \\
\hline Eggs & 1.3 & 3.2 & 9.2 & $\mathrm{p}<0.001$ \\
\hline Peanuts & 2.1 & 3.0 & 10.2 & $\mathrm{p}<0.001$ \\
\hline Hazelnuts and other nuts & 3.0 & 4.3 & 12.2 & $\mathrm{p}<0.001$ \\
\hline Fish & 0.8 & 1.1 & 4.1 & $\mathrm{p}<0.05$ \\
\hline Seafood & 0.2 & 0.7 & 3.1 & $\mathrm{p}<0.05$ \\
\hline Celery & 0.4 & 1.6 & 3.1 & $\mathrm{p}=0.052$ \\
\hline Fruit, including citrus & 7.4 & 8.2 & 16.3 & $\mathrm{p}<0.05$ \\
\hline Soybeans & 0.2 & 1.8 & 1.0 & $\mathrm{p}<0.05$ \\
\hline Poultry & 0.0 & 0.5 & 2.0 & $\mathrm{p}<0.05$ \\
\hline Pork, beef & 0.4 & 0.7 & 2.0 & $\mathrm{p}=0.214$ \\
\hline Wheat/ gluten & 2.7 & 2.3 & 1.0 & $\mathrm{p}=0.585$ \\
\hline Food additives & 2.7 & 3.2 & 6.1 & $\mathrm{p}=0.231$ \\
\hline Other & 6.3 & 5.9 & 11.2 & $\mathrm{p}=0.155$ \\
\hline & & & &
\end{tabular}




\section{DISCUSSION}

Key results. The results of this multicentre study demonstrate that individuals with allergic multimorbidity (i.e. those diagnosed with more than one allergic disease of AR, BA or AD) suffer from food allergy or food intolerance more often than individuals not diagnosed with allergic multimorbidity.

Of all food products listed in the questionnaire, symptoms of food allergy or food intolerance were most often produced by dairy products (milk and milk products) and fruit, including citrus.

The study data reveal that allergic multimorbidity is associated with a much higher prevalence of food sensitisation compared with the presence of one of the 3 allergic diseases. The reverse correlation was identified only for soybean- and wheat/gluten-containing foods.

Limitations. A limitation of the study was the narrow interpretation of allergic multimorbidity as the presence of 2 or more of 3 allergic diseases (AR, AD, BA). The study only accounted for the types of food most often causing food allergy or food intolerance.

The study had a cross-sectional design, and all data about food allergy and intolerance were as declared by the participants. Amy S. Paller et al. elaborate particularly on the design of food allergy studies, stating that a well-designed study of food allergy should be based on testing or food challenge tests rather than history-taking alone [31]. At the same time, there is no consensus on testing for food allergy.

Interpretation. The increasing prevalence of allergic diseases worldwide is resulting in intensified efforts to identify the underlying causes and background, as well as indicating risk factors for these conditions. Research on correlations between allergic multimorbidity and food allergy supplies additional information in this respect $[32,33]$.

The findings of the current study indicate that there is an association between food allergies and the presence of at least one allergic disease of AR, BA and AD. Prifits et al. found that children with diagnosed food allergy developed asthma over the next several years [34]. Julie Wang et al. also studied the association between food allergies and asthma and demonstrated that the presence of food allergies correlated with asthma severity [35]. Similar findings were obtained in a study by Roberts et al. [36]. R. Jaramilo, in a study of 8,203 participants, found that patients with doctordiagnosed asthma demonstrated allergic responses to food more often than individuals without a diagnosis of asthma (27.5\% vs. $14.9 \%$ ) [38], which also confirms the hypothesis that asthma influences food allergies. Marcel M. Bergmann states that a third of children with $\mathrm{AD}$ have a documented food allergy. The author also believes that cow's milk is the most common allergen responsible for AD and FA symptoms in children. His claims are also supported by the findings of Dhar S. et al., as well as by the results of the current study $[39,40]$. Teresa Tsakok et al. confirmed a strong association between $\mathrm{AD}$ and food allergy. In an analysis of 66 studies, they found that in population-based studies, the risk of an untoward response to a food was about 6 -fold greater in patients with AD than in healthy individuals. Studies of patients diagnosed with $\mathrm{AD}$ reported food allergies in as many as $81 \%$ of the subjects [41].
The presented study shows that the risk of allergy to or intolerance of fruit, and in particular citrus, was higher in individuals suffering from one or more allergic diseases. These data confirm the findings of Mohammed W. Al-Rabia, indicating a link between AR and food allergy or intolerance. The author states that allergic rhinitis is a widespread condition affecting up to $40 \%$ of the population, and some patients experience an itching and burning sensation in the throat associated with AR symptoms after eating fruit and vegetables [42].

Rashid Al-Abri et al. confirm the co-presence of food allergies and allergic rhinitis. A prospective cohort study in Sweden found that $40 \%$ of infants with FA went on to develop AR by the age of 8 years. It was also demonstrated that AR may precede food allergy, with $47 \%$ of the children developing food allergies within the first year of life, while $7.9 \%$ of children with AR developed food allergies by the second year of life [43]. Syed M. Tariq et al. showed that allergies to dairy products in children with concomitant $\mathrm{AD}$ and respiratory symptoms were associated with severe symptoms in later life [44]. This is compatible with the current findings, indicating an association between allergic multimorbidity and food allergy and intolerance.

The relationships between specific allergic diseases discussed in this study were also analysed by N. Nicolaou et al., who confirmed the co-occurrence of allergic diseases. In addition, their results showed that there are pairs of allergic diseases characteristic of urban or rural areas. It has been noted, for example, that for urbanized areas the correlation of atopy with asthma is characteristic, while in rural areas atopy occurs more often with non-asthmatic wheezing [45].

\section{CONCLUSIONS}

Food allergy or food intolerance was more common in subjects with allergic multimorbidity than in subjects diagnosed with one allergic disease, or those free of allergic diseases. The study also confirmed the role of milk and milk products as the most common cause of FA symptoms.

\section{REFERENCES}

1. Igea JM. The history of the idea of allergy. Allergy. 2013; 68(8): 966-73. https://doi.org/10.1111/all.12174

2. Butrym I, Płaczkowska S, Pawlik-Sobecka L, Smolińska S. Podstawowe testy wykorzystywane w diagnostyce alergii IgE-zależnej i alergii kontaktowej. Diagnostyka Laboratoryjna. 2017; 53(3): 169-174.

3. European Allergy White Paper, The UCB Institute of Allergy. Allergic diseases as a public health problem in Europe. UCB Institute of Allergy 1997.

4. Ibrahim NK, Alghamdi AA, Almehmadi MM, Alzahrani AA, Turkistani AK, Alghamdi K. Allergy and related clinical symptoms among medical students and interns. Pak J Med Sci. 2019; 35: 1060 1065. https://doi.org/10.12669/pjms.35.4.1281

5. Samoliński B, Raciborski F, Lipiec A, et al. Epidemiologia chorób alergicznych w Polsce ECAP. Alergol Pol. 2014; 1: 10-8. https://doi. org/10.1016/j.alergo.2014.03.008

6. European Community Respiratory Health Survey: Variations in the prevalence of respiratory symptoms, self- reported asthma, and use of asthma medication in the European Community Respiratory Health Survey. Eur Respir J. 1996; 9: 687-695.

7. Lipiec A, Wawrzyniak ZM, Sybilski AJ, et al. The association between paracetamol use and the risk of asthma, rhinitis and eczema in the Polish population. Ann Agric Environ Med. 2018; 25(3): 428-432. https://doi.org/10.26444/aaem/86336 
8. Van Niekerk CH, Weinberg EG, ShoreSC, Heese HV, Van Schalkwyk J. Prevalence of asthma: a comparative study of urban and rural Xhosa children. Clin Allergy 1979; 9: 319-324. https://doi. org/10.1111/j.1365-2222.1979.tb02489.x

9. Riedler J, Eder W, Oberfeld G, Schreuer M. Austrian children living on a farm have less hay fever, asthma and allergic sensitization. Clin Exp Allergy. 2000; 30: 194-200. https://doi.org/10.1046/j.13652222.2000.00799.x

10. Radlović N, Leković Z, Radlović V, Simić D, Ristić D, Vuletić B. Food allergy in children. Srp Arh Celok Lek. 2016; 144(1-2): 99-103. https://doi.org/10.2298/SARH1602099R

11. Ebisawa M, Ito K, Fujisawa T, Committee for Japanese Pediatric Guideline for Food Allergy, The Japanese Society of Pediatric Allergy and Clinical Immunology, The Japanese Society of Allergology. Allergol Int. 2017; 66(2): 248-264. https://doi.org/10.1016/j.alit.2017.02.001

12. Sicherer SH, Sampson HA. Food allergy: a review and update on epidemiology, pathogenesis, diagnosis, prevention, and management. J Allergy Clin Immunol. 2018; 141(1): 41-58. https://doi.org/10.1016/j. jaci.2017.11.003

13. Yu W, Freeland DMH, Nadeau KC. Food allergy: Immune mechanisms, diagnosis and immunotherapy. Nat Rev Immunol. 2016; 16: 751-765.

14. Crowe SE. Food Allergy Vs Food Intolerance in Patients With Irritable Bowle Syndrome. Gastroenterol Hepatol (N.Y). 2019; 15(1): 38-40.

15. Agache I, Aojanu C, Laculiceanu A, Rogozea L. Critical Points on the Use of Biologicals in Allergic Diseases and Asthma. Allergy Asthma Immunol Res. 2020. (1): 24-41. http://dx.doi.org/10.4168/ aair.2020.12.1.24

16. Bednarek A, Klepacz R, Surtel A, Mazur A, Saran T, Zarzycka D, et al. Influence of environment on residence and selected demographic and clinical parameters of preschool children with IgE-dependent asthma. Ann Agric Environ Med. 2019; 26: 439-444. https://doi.org/10.26444/ aaem/104666

17. Nutten S. Atopic dermatitis: global epidemiology and risk factors. Ann Nutrit Metab. 2015; 66(Suppl 1): 8-16.

18. Cabanillas B, Brehler AC, Novak N. Atopic dermatitis phenotypes and the need for personalized medicine. Curr Opin Allergy Clin Immunol. 2017; 17: 309-315.

19. Thomsen SF. Atopic dermatitis: Natural history, diagnosis, and treatment. ISRN Allergy. 2014; 2014: 354250. https://doi.org/10.1155/2014/354250

20. McPherson T. Current Understanding in Pathogenesis of Atopic Dermatitis. Indian J Dermatol. 2016; 61(6): 649-655.

21. Sybilski AJ, Raciborski F, Lipiec A, et al. Atopic dermatitis is a serious health problem in Poland. Epidemiology studies based on the ECAP study. Postepy Dermatol Alergol. 2015; 32: 1-10. https://doi.org/10.5114/ pdia.2014.40935

22. Brzoznowski W. Standardy diagnostyczne i terapeutyczne alergicznego nieżytu nosa. Forum Med Rodz. 2009; 3(3): 173-180.

23. Head K, Snidvongs K, Glew S, Scadding G, Schilder AG, Philpott C, et al. Saline irrigation for allergic rhinitis. Cochrane Datab Syst Rev. 2018; 6. https://doi.org/10.1002/14651858.CD012597.pub2

24. Samoliński B, Raciborski F. Znaczenie AZS w wielochorobowości alergii. I. Interdyscyplinarna Akademia Atopii. 2017.

25. Megna M, Napolitano M, Patruno C, Villani A, Balato A, Monfrecola G, et al. Systemic treatment of adult atopic dermatitis: a review. Dermatol Ther (Heidelb). 2017; 7(1): 1-23.

26. Humbert M, Bousquet J, Bachert C, Palomares O, Pfister P, et al. IgE-Mediated Multimorbidities in Allergic Asthma and the Potential for Omalizumab Therapy. J Allergy Clin Immunol Pract. 2019; 7(5): 1418-1429. https://doi.org/10.1016/j.jaip.2019.02.030

27. Krogulska A. Znaczenie alergenów pokarmowych u dzieci i dorosłych $\mathrm{z}$ alergią wziewną. Alergia Astma Immunol. 2016; 21(1): 16-27.
28. Hanif T, Laulajainen-Hongisto A, Numminem J, Kääriäinen J, Myller J, et al. Hierarchical clustering in evaluating inflammatory upper airway phenotypes; increased symptoms in adults with allergic multimorbidity. Asian Pac J Allergy Immunol. 2019. https://doi.org/10.12932/AP170818-0395

29. Raciborski F, Bousquet J, Namysłowski A, Krzych-Fałta E, Tomaszewska A, Piekarska B, Samel-Kowalik P, Białoszewski AZ, Walkiewicz A, Lipiec A, et al. Dissociating polysensitization and multimorbidity in children and adults from a Polish general population cohort. Clin Transl Allergy. 2019; 9: 23. https://doi.org/10.1186/s13601-019-0246-y

30. Prescott SL, Pawankar R, Allen KJ. Campbell D. A global survey of changing patterns of food allergy burden in children. World Allergy Organ J. 2013; 6(1): 21. https://doi.org/10.1186/1939-4551-6-21

31. Paller AS, Spergel JM, Mina-Osorio P, Irvine AD. The atopic march and atopic multimorbidity: Many trajectories, many pathways. J Allergy Clin Immunol. 2019; 143(1): 46-55. https://doi.org/10.1016/j. jaci.2018.11.006

32. Lack G. Update on risk factors for food allergy. J Allergy Clin Immunol. 2012; 129(5): 1187-1197. https://doi.org/10.1016/j.jaci.2012.02.036

33. Licari A, Manti S, Marseglia A, et al. Food Allergies: Current and Future Treatments. Medicina (Kaunas). 2019 May; 55(5): 120. https:// doi.org/10.3390/medicina55050120

34. Priftis KN, Mermiri D, Papadopoulou A, Papadopoulos M, Fretzayas A, Lagona E, et al. Asthma symptoms and bronchial reactivity in school children sensitized to food allergens in infancy. J Asthma. 2008; 45(7): 590-5. https://doi.org/10.1080/02770900802032941

35. Wang J, Visness CM, Sampson HA. Food allergen sensitization in inner-city children with asthma. J Allergy Clin Immunol. 2005; 115: 1076-1080. https://doi.org/10.1016/j.jaci.2005.02.014

36. Arabkhazaeli A, Vijverberg SJ, van Erp FC, Raaijmakers JA, van der Ent CK, van der Maitland Zee AH. Characteristics and severity of asthma in children with and without atopic conditions: a cross-sectional study. BMC Pediatr. 2015; 15: 172.

37. Roberts G, Patel N, Levi-Schaffer F, Habibi P, Lack G. Food allergy as a risk factor for life-threatening asthma in childhood: a case-controlled study. J Allergy Clin Immunol. 2003; 112(1): 168-174.

38. Jarmillo R, Massing M, Sicherer S, et al. High-level sensitization to foods is associated with asthma ER visits and current asthma in the US: results from NHANES 2005-2006. J Allergy Clin Immunol. 2009; 123: 2-419. https://doi.org/10.1016/j.jaci.2008.12.404

39. Dhar S, Srinivas SM. Food allergy in atopic dermatitis. Indian J Dermatol. 2016; 61: 645-8.

40. Bergmann M, Caubet J, Boguniewicz M, Eigenmann P. Evaluation of food allergy in patients with atopic dermatitis. J Allergy Clin Immunol Pract. 2013; 1(1): 22-8. https://doi.org/10.1016/j.jaip.2012.11.005

41. Tsakok T, Marrs T, Mohsin M, Baron S, du Toit G, Till S, Flohr C. Does atopic dermatitis cause food allergy? A systematic review. J Allergy Clin Immunol. 2016; 137(4): 1071-1078. https://doi.org/10.1016/S01406736(17)30491-9

42. Al-Rabia MW. Food-induced immunoglobulin E-mediated allergic rhinitis. J Microsc Ultrastruct. 2016; 4: 69-75.

43. Al-Abri R, Al-Amri AS, Al-Dhahli Z, Varghese AM. Allergic rhinitis in relation to food allergies: Pointers to future research. Sultan Qaboos Univ Med J. 2018; 18(1): 30-3. http://dx.doi.org/10.18295/ squmj.2018.18.01.005

44. Tariq SM, Matthews SM, Hakim EA, Arshad SH. Egg allergy in infancy predicts respiratory allergic disease by 4 years of age. Pediatr Allergy Immunol. 2000; 11: 162-167. https://doi.org/10.1034/j.13993038.2000.00077.x

45. Nicolaou N, Siddique N, Custovic A. Allergic disease in urban and rural populations: increasing prevalence with increasing urbanization. Allergy. 2005; 60: 1357-60. 